\title{
STEM Education in Malaysia towards Developing a Human Capital through Motivating Science Subject
}

\author{
Fazilah Razali, Umi Kalthom Abdul Manaf and Ahmad Fauzi Mohd Ayub \\ Universiti Putra Malaysia \\ Selangor, Malaysia \\ https:// orcid.org/0000-0002-1203-1010 \\ https://orcid.org/0000-0002-4793-8165 \\ https://orcid.org/0000-0002-4313-2922
}

\begin{abstract}
This paper focuses on the motivational factor in learning science encompassing the elements of self-efficacy, self-determination, intrinsic, grade, and career. These factors identified from previous research have a direct influence on the conception of careers related to Science, Technology, Engineering, and Mathematics (STEM) among students. This study is a quantitative study using two surveys: Motivational Science Questionnaire (MSQ II) and career interest in STEM from the STEM Student Questionnaire (S-STEM). The questionnaire was modified and tailored to the purpose of this investigation. The objective of this research is to determine motivation as the main factor in science to develop students' interest in a STEM career among secondary students in Malaysia. A total of 419 Form Four students were the respondents of this study. The results show that motivation of indirect science learning can influence the development of Form 4 students' interest in STEM careers. The data were analyzed using the Structural Equation Modeling (SEM) method which is in line with the self-determination theory to determine the strong influence of motivation on students' career. The result shows a very high influence of motivation towards science with a significantly high variance of $51 \%$ on the development of interest in STEM-related careers among Malaysian students.
\end{abstract}

Keywords: STEM; science curriculum; structural equation modelling (SEM); careers; Malaysia

\section{Introduction}

Reeve (2015) has defined the elements of Science, Technology, Engineering, and Mathematics in the education system as follows: science is a study related to nature, while technology serves as a tool to change the natural world to meet the needs and wants of society. Engineering uses mathematics and science to produce technology in which Mathematics represents the language of numbers, patterns, 
and relationships that relate to science, technology, and engineering as a whole. Although there are various definitions used to translate STEM into the education system, the goal of the STEM education system is to build the capacity of every student to meet the needs of the STEM industry and is an ongoing process (Halim, 2018). The awareness of the importance of science has been given the necessary attention, especially in the education system to produce more labour who are skilled in STEM to support the country's economy. This effort will bring about a positive impact on students' involvement as a result of early exposure to the importance of scientific knowledge and its relation to STEM careers, if channelled in a more transparent and structured manner. Due to the emphasis of STEM careers, the Ministry of Education (MOE) seriously took up the suggestions of the National Education Blueprint (PPPM) 2013-2025. The idea to change the existing curriculum to the Standard Secondary School Curriculum (SSSC) is by strengthening and introducing STEM in the education system of Malaysia as one of the pillars in the new curriculum.

Students' motivation for science is more meaningful when students have an awareness of science for everyday life necessities. The motivation for science among students plays an essential role in enabling the consistency of students' career choice in the field of STEM (Duschl, 2019). Motivation is also an essential element of the long-term need for science learning based on self-determination theory that includes elements of self-efficacy, self-determination, achievement, and intrinsic motivation to achieve learning goals (Lee, 2017). Furthermore, Guan et al. (2016) emphasize that motivation can provide ongoing internal support throughout STEM students' exploration. The motivation for high science also provides students with the opportunity to develop an ongoing interest in STEM careers (McFadden \& Roehrig, 2020). Therefore, the importance of motivation in refining students' needs in the learning process of STEM career development is essential for the unity of students' knowledge and preparation in the STEM industry sector.

\section{Literature Review}

The formation of a new and established curriculum will only be meaningful if it is in line with the students' readiness to master knowledge in science. At the same time, students can use the knowledge to build up their interest in STEM and directly will fulfil students' career aspirations (Li et al., 2020). STEM needs to be translated in teaching and learning holistically to students' so that they develop a positive attitude towards STEM as well as to increase 21st-century learning skills among them (Bergeron \& Gordon, 2015; Zeynep, Dokme \& Unlu, 2016). Besides, the ability of teachers to understand students' needs can also help develop the students' motivation and potential (Dare, Ellis \& Roehrig, 2018).

\subsection{Self-determination theory}

Self-determination theory is a macro motivational theory of humans that is essential across domains including parenting, education, physical activities, and work management or tasks (Deci, Olafsen \& Ryan, 2017). The self-determination theory is also a comprehensive framework which stresses on the students' tendency towards doing something of their interests based on their knowledge 
and skills (Beerenwinkel \& von Arx, 2016). Therefore, motivation to study science is the ability of students that will also influence the formation of positive reinforcement which influences autonomous motivation and controlled motivation (Nguyen \& Deci, 2016).

Autonomy involves behaviours that are followed by will based on the environmental pressures which influence motivations towards a more positive outlook. Intrinsic motivation is autonomous motivation that when students are interested in a particular matter, they will try to pursue it. On the contrary, controlled motivation involves behaviours to reach on pressure or influence that concern a specific action and the hope on students' performance. Autonomous motivation and controlled motivation are both components in motivation that influence students' interest and motivation in choosing a preferable career (Olafsen et al., 2017). In conjunction with the importance of theory to encourage the formation of positive motivation, especially towards a more specified Science curriculum by correlating it with careers in the scientific field (Dare, Ellis \& Roehrig, 2018).

\subsection{Motivation towards Science and STEM Career}

Motivation in learning refers to ways of students think about themselves by taking account of students' preparedness in-process and self-learning activities which are also able to give students consistency towards focused learning (Hora \& Oleson, 2017). Motivation to learn has two categories which are 1) intrinsic motivation related to self-perception and environmental influences, 2) extrinsic motivation is controlled by performance, rewards, and learning objectives of students (Adegboyega, 2018; Gagné \& Deci, 2005).

Therefore, students need to know the relationship between Science curriculum which is learned with the needs to achieve career aspiration among students to increase their motivation to continue learning Science (Sheldrake, 2016; Soni \& Kumari, 2015). Besides, motivation is the element of self-determination to make efforts in learning science and have the potential to encourage the formation of interest better towards a science career (Leung, 2020). Therefore, motivation is vital in ensuring that input received by students is used to see science to the needs of producing STEM skilled labour.

Also, motivation is essential to influence choice and students' consistent involvement in science stream and careers in STEM-related fields (Duschl, 2019). Thus, the importance of motivation will always be the primary matter in the learning process to achieve the actual curriculum goals. Moreover, high motivation will not only help students to succeed but also will assist students in seeing the value in science curriculum learned with the direction of forming career interest for the future (Beerenwinkel \& von Arx, 2016; Hamjah, Ismail, Rasit \& Rozali, 2011; Khong, Hassan \& Ramli, 2017).

Motivation in learning science is needed to ensure students can use the science knowledge capacity and skills in forming careers that are in line with the students' interest. Furthermore, this research investigates motivation in science among 
Form 4 students of Science stream in a national secondary school situated in Selangor for the Malaysian context. The emphasis of students' STEM-related careers (a) determines science motivation is significant towards the formation of STEM-associated careers, (b) whether the influence of science motivation gives impacts and its contribution towards the establishment of STEM-related careers among science-stream students in Malaysia.

\section{Methodology}

\subsection{Research and Respondents}

The study was conducted in a densely populated state in Selangor, Malaysia. Through random selection, ten districts (Hulu Selangor, Gombak, Petaling Perdana, Petaling Utama, Hulu Langat, Sepang, Klang, Kuala Langat, Kuala Selangor dan Sabak Bernam) are represented. The study covered 419 Form 4 science stream students in Sekolah Menengah Kebangsaan in Selangor using the Proportionate Stratified Random Sampling. This method is suitable to describe the population of science students in Selangor into sub-populations. The location was selected based on the information sought from Table 1, in which it reported that Selangor was the first state in the country to be exposed to STEM information.

Table 1: Population Distribution and Secondary School Students in Selangor

\begin{tabular}{|c|c|c|}
\hline $\begin{array}{c}\text { Distribution of } \\
\text { population }\end{array}$ & $\begin{array}{c}\text { Total Number of } \\
\text { Secondary Schools }\end{array}$ & $\begin{array}{c}\text { Number of Secondary } \\
\text { School Students }\end{array}$ \\
\hline $6,140.1$ & 272 & 404,835 \\
\hline
\end{tabular}

The research respondents were random selected from these schools (Table 2). However, this research does not substantiate further on gender since it is merely additional information in the study to observe a balanced sample of Malaysia, especially Selangor students who took a science stream in secondary schools.

Table 2: Result of the descriptive analysis based on the gender of a sample of students

\begin{tabular}{|c|c|c|}
\hline Gender & Frequency & Percentage \\
\hline Male & 196 & 46.8 \\
\hline Female & 237 & 53.2 \\
\hline Total & 419 & 100.0 \\
\hline
\end{tabular}

\subsection{Research Instrument}

The Science Motivation Questionnaire II (SMQ II) (Appendix 1 \& 2) is a psychometric tool used to assist students in identifying motivation in learning science to achieve good mastery in scientific knowledge. Students will be able to see the importance of motivation in learning science on the formation of their future careers (Glynn et al., 2011). This survey aims to measure students' motivation in science. The questionnaire had 25 items encompassing five subconstructs: intrinsic motivation, self-efficacy, self-determination, achievement, and career in order to measure students' motivation in pursuing a STEM career. 
Each construct consists of 5 items. This survey measures every single scope of STEM career fields such as engineering, science, technology, space, agriculture, and mathematics. The survey has been adapted in the Malay language to suit the items with the students' environment which is the primary language of instruction in the Malaysian education system. The questions are presented in an interval scale of 1 (strongly disagree) to 10 (strongly agree). Respondents need to choose answers by checking the range based on the accuracy of the question and their abilities. This study is a full-fledged quantitative research. After the data were collected, the researchers analyze it using the Structural Equation Modelling (SEM) method.

\subsection{Procedures}

Before the fieldwork, the instrument must go through the reliability and validity procedure through a pilot study to ensure reliable and valid data to the next analysis step. Expert validation for the questionnaire was carried out in terms of the scale used and item content to represent construct implementation prior to the pilot study. Three experts from the teaching profession and STEM have validated the SMQ II and S-STEM (STEM Career) instrument.

From the pilot study analysis based on the correlation of minimum value scores of each item with the total scores is in accordance with the constructs in this study. This validating method is in line with the theory introduced by Nunally (1967). Based on Nunally \& Bernstein (1994), the correlation value that is over .25 has a high validity. Therefore, SMQ II instrument is valid because it shows the correlational mean value of each item with the total score according to the construct of each instrument over .25 and can be measured appropriately in Table 3. The Cronbach's alpha value instruments presented in this research have high reliability and validity (Table 3) as well. According to Sekaran (2013), an alpha value over .80 is considered good, and therefore the instrument is reliable.

Table 3: Summary of Validity and Reliability Report for the instrument

\begin{tabular}{|c|c|c|}
\hline Instrument & $\begin{array}{c}\text { Correlation of Mean Value between } \\
\text { Scores of Each Item with Total Score }\end{array}$ & $\begin{array}{c}\text { Cronbach } \\
\text { Alpha }\end{array}$ \\
\hline $\begin{array}{c}\text { Science Motivation } \\
\text { Questionnaire II (SMQ-II) }\end{array}$ & .591 & 0.972 \\
\hline S-STEM (Career STEM) & .543 & 0.811 \\
\hline
\end{tabular}

\section{Results}

\subsection{Confirmatory Factor Analysis (CFA)}

The data will then be analyzed using Structural Equation Model (SEM) to measure the direct influence and effects of motivation in science which is also a latent factor in the formation of interest in STEM-related careers. Before looking at the direct impact of the science motivation, a Confirmatory Factor Analysis (CFA) is used to determine the data of science to fulfil the fixed indices. In general, the measurement model satisfies the majority index compatibility value of a model for each category, thus, this measurement model is suitable and a good model (Schreiber et al., 2006). 
Figure 1 shows the measurement model in CFA on the data of science motivation through the SMQ II and shows that science motivation can fulfil at least one index for each category. The figure shows the symbol KERSTEM (STEM career) and MOTIVASI (motivation) with the element of EFI (self-efficacy), KEN (selfdetermination), INT (intrinsic), GRE (grade) and KER (career). The modification process has been implemented on the measurement model to ensure the items that have a low loading factor and the only question (item) with the necessary loading factor to fit the indexes measurement model (Awang, 2015).

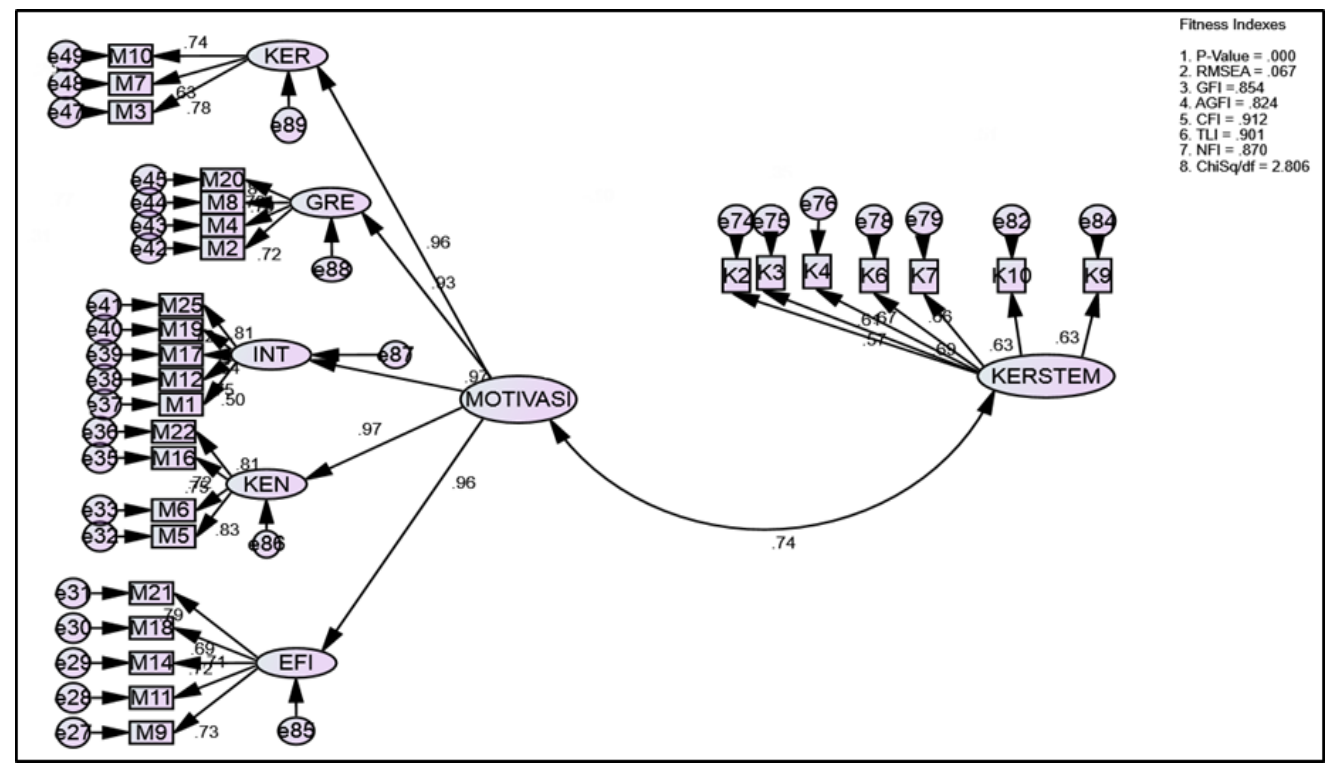

*Motivation (Motivasi) and STEM Career (KERSTEM)

Figure 1: Measurement Model on Science Motivation and STEM Related Career

Based on the analysis result, it shows that the measurement model passed the majority fit index value that involved all three categories which were Chisq, RMSEA, CFI, TLI, Chisq/df, and the value of $p$ (Figure 1). As stated by Schreiber et al., (2006), a measurement model that fulfils the majority of the model fit indexes value shows that it is a good and acceptable model.

Table 4: Index of Measurement Model Compatibility based on Hair Index et al. (2010)

\begin{tabular}{|l|c|c|c|}
\hline Category & Name of Indexes & $\begin{array}{c}\text { Acceptable } \\
\text { Indexes }\end{array}$ & $\begin{array}{c}\text { Index of } \\
\text { Measurement Model }\end{array}$ \\
\hline \multirow{3}{*}{ 1. Absolute fit } & Chisq & $>0.05$ & 942.880 \\
\cline { 2 - 4 } & RMSEA & $<0.08$ & .067 \\
\cline { 2 - 4 } & GFI & $>0.90$ & .854 \\
\hline \multirow{3}{*}{$\begin{array}{l}\text { 2. Incremental } \\
\text { fit }\end{array}$} & AGFI & $>0.90$ & .824 \\
\cline { 2 - 4 } & CFI & $>0.90$ & .912 \\
\cline { 2 - 4 } & TLI & $>0.90$ & .901 \\
\cline { 2 - 4 } $\begin{array}{l}\text { 3. Parsimonious } \\
\text { fit }\end{array}$ & NFI & $>0.90$ & .870 \\
\hline \multirow{2}{*}{$\begin{array}{l}\text { 4. The goodness } \\
\text { of fit index }\end{array}$} & Chisq/df & $<0.50$ & 2.806 \\
\cline { 2 - 4 } & TLI & $>0.90$ & .912 \\
\cline { 2 - 4 } & GFI & $>0.90$ & .901 \\
\hline
\end{tabular}


Table 4 shows that the measurement model can fulfil the majority of fixed indexes. Based on Hair et al. (2010), compatibility indexes to evaluate the model needs to achieve one of the indexes from the category in Table 5. Therefore, the study has made a majority of index values, at least one index, fit into each index category, which is the value indexes based on Chisq ( $\left.\mathrm{X}^{2}\right)$, RMSEA, CFI, TLI, and Chisq/df. However, the index value is advisable to measure the compatibility index on the measurement model in CFA which is RMSEA, CFI, and Chisq/df for continuous data (Hooper, Coughlan \& Mullen, 2008; Hu \& Bentler, 1998). Research involves continuous data and has fulfilled the majority of the index needed for the compatibility measurement model to analyze the determining factors.

Table 5: Category for each index

\begin{tabular}{|l|c|}
\hline Category & Index \\
\hline Absolute fit & RMSEA or GFI \\
\hline Incremental fit & CFI or TLI \\
\hline Parsimonious fit & Chisq/df \\
\hline Goodness of fit index & CFI or TLI or GFI \\
\hline
\end{tabular}

\subsection{Validity and Reliability of the Measurement Model}

As soon as the CFA procedure for a particular measurement model is completed, it is essential for several steps to be conducted as a procedure for the validity and reliability of constructs. The evaluation of uni-dimensionality, validity, and reliability of the measurement model is needed before the formation of the model structure. Uni-dimensionality is achieved by discarding items which have a low loading factor. The new model in the modification process and the item discarded the operation until the fitness indexes achieve the desired levels.

Validity needs are achieved based on the following criteria: convergent validity AVE $\geq 0.50$ (Table 6); construct validity - to fulfil the level of indexes required; discriminant validity - there are no overlapping items (MI) discarded or "free parameter" for all the research constructs (Table 6). Reliability requirements occur during specific processes, as follows: internal reliability - Alpha Cronbach $\geq .70$ (Table 6) and composite reliability - CR $\geq 0.6$ (Table 6).

Table 6: Confirmatory Factors Analysis for Scientific Motivation Construct

\begin{tabular}{|l|c|c|c|c|}
\hline Construct & $\begin{array}{c}\text { Discarded } \\
\text { items }\end{array}$ & $\begin{array}{c}\text { Alpha Cronbach } \\
(\mathbf{8} \mathbf{0 . 7})\end{array}$ & CR ( $\mathbf{2 0 . 6})$ & AVE ( $\mathbf{0 . 5 )}$ \\
\hline Scientific motivation & $\begin{array}{c}\text { M13, M16, } \\
\text { M23, M24 }\end{array}$ & .956 & .96 & .54 \\
\hline $\begin{array}{l}\text { Interest in STEM-related } \\
\text { careers }\end{array}$ & $\begin{array}{c}\text { K1, K5, K8, } \\
\text { K11, K12 }\end{array}$ & .807 & .89 & .50 \\
\hline
\end{tabular}

The value of average extracted variance (AVE) and composite reliability coefficient (CR) were related to the quality of measurement. To avoid misconceptions, it is necessary to understand the AVE and CR along with their relation to validity and reliability. The formulas of CR and AVE for scientific motivation and interest in STEM-related career are:

$$
\left.\mathbf{C R}=(\Sigma \mathrm{K})^{2} /\left[(\Sigma \mathrm{K})^{2}+\Sigma 1-\mathrm{K}^{2}\right)\right] ; \mathbf{A V E}=\Sigma \mathrm{K}^{2} / \mathrm{n} .
$$


Table 7: Correlation between measurement constructs of the instrument.

\begin{tabular}{|l|c|c|}
\hline Constructs & Science motivation & STEM career interests \\
\hline Science Motivation & ${ }^{*} .734$ & ${ }^{* *} .731$ \\
\hline STEM career interests & ${ }^{* *} .731$ & ${ }^{*} .707$ \\
\hline
\end{tabular}

* Square root of AVE

** Correlation between constructs $(<.85)$

The coefficient values shown in bold in Table 7 are the square root of two AVE values for each construct. The model achieved the discrimination validity when the coefficient values in bold are high in values compared to the values in the rows and columns that represent correlational values for each construct based on the measurement (Awang, 2015).

\subsection{Structural Model}

The structural model connects the two independent variables to the dependent variable. This structural model represents the magnitude and direction of influence between two sets of the latent variable by enabling the researcher to evaluate the relationship between variables based on the impact measured in the model. The structural model is defined as the relationship between the latent variables by using the maximum likelihood method (Hair et al., 2010). The structural model serves to create specifications related to latent variable influences on other latent variables in the model directly. The structural model can also contribute specifications regarding how a latent variable can predict other latent variables in a similar model. Besides, the strength of SEM is to analyze the relationship amongst other latent constructs that are involved in the SEM technical model with the SEM techniques that can give more accurate solutions (Hair et al., 2014).

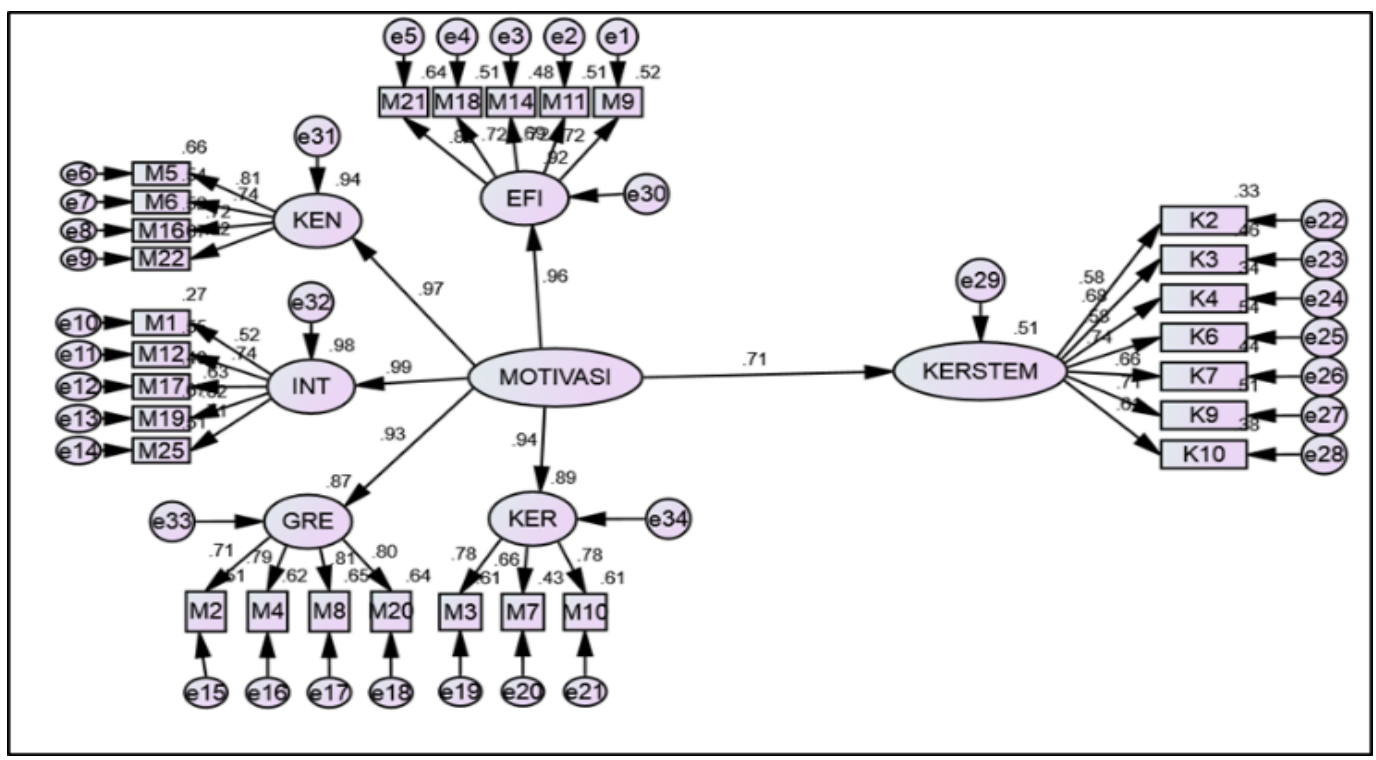

*Motivation (MOTIVASI) and STEM Career (KERSTEM)

Figure 2: Structural Model between Motivation to Learn Science and STEM Careers

Figure 2 shows the result of objective testing to determine the influence directly on motivation towards the formation of interest in STEM-related careers. The 
screening to answer the objective measurement which is to assess the significance of scientific motivation on students' interest in STEM-related careers and either the scientific motivation influence and its contribution to the formation of students' interest in STEM-related careers among science stream students in Malaysia. In response to the study objectives (a) of the Standard Regression Standard (Table 8), the high standard deviation of .713 as well as the influence of scientific motivation also significantly directly influence students' interest in STEM careers with $\mathrm{p}$-value $=.001$. Additionally, the direct impact of independent variable and determination of moderator influence is significant at $p<0.05$ as well as the foundation of the rows in Science Social fields (Aytekin et al., 2016).

Table 8: Standardized Regression Weights

\begin{tabular}{|c|c|c|c|c|c|c|}
\hline \multicolumn{3}{|c|}{ Constructs } & Estimate & S.E. & C.R. & P \\
\hline KERSTEM & $<--$ & MOTIVATION & .713 & .062 & 9.612 & $* * *$ \\
\hline
\end{tabular}

The second objective was to study the influence of motivation in science and its contribution to the formation of interest in STEM-related careers among science stream students in Malaysia. This objective can be explained through the variance obtained for the Squared Multiple Correlation $\left(\mathrm{R}^{2}\right)$ which is .509 or $51 \%$. The general effect of the $R^{2}$ variance is estimated to be significant when $R^{2}$ is 0.30 or $30 \%$ contribution (Kline, 2011). This estimation is by the independent variable to the dependent variable. Thus, it is agreed that science motivation has a strong influence and can expect a large contribution towards the formation of interest in STEM-related careers among Form 4 science stream students in Selangor.

\section{Discussion}

The analysis conducted showed that science motivation has a significant direct influence in explaining the importance of science motivation towards the formation of STEM-related careers among students. Besides, motivation in learning science directly influences the environmental adaptability of students' learning process in choosing study programs related to STEM careers (Fazilah et al., 2020). The results have also shown that the combination of elements such as self-efficacy, self-determination, intrinsic motivation, grades, and career are needed to measure science motivation more thoroughly to inform students' interest towards STEM-related careers. Therefore, it is essential to integrate the element of science motivation in lesson planning to provide new inputs to the students through the knowledge of science for the future (Khodabakhszadeh et al., 2018). The finding for effects of the direct influence also showed high impacts and the immense contribution of science motivation towards the formation of interest in STEM-related careers. The variance of $51 \%$ shows the strong influence of science motivation on the formation of interest in STEM-related careers among Form 4 science stream secondary schools' students in Malaysia. This study has been able to explain precisely the validity and the importance of science motivation to improve students' tendency to join learning programs in the STEM fields when they will enroll for tertiary education. Nevertheless, further studies need to be done to address more variables that can attract students' interest in STEM careers. 


\section{Conclusion}

These findings can become a reference for different streams as well as STEM fields especially to determine students' motivation towards science to develop an interest in STEM careers because the questionnaire used in this study focuses on self-determination, grade, efficacy, intrinsic motivation, and career. STEM is a broad field, but some modifications must be done in terms of content, demographic questionnaires, and theories to adapt it the environment or research issues. The STEM field impacts unlimited model usage among science stream students. Other streams such as Technical Communication Graphics, Supplementary Science, Agriculture, Home Science, Design, Computer Science, and Sports Science are also considered a STEM field at the secondary level. Research on the need for scientific motivation using Structural Equation Modeling (SEM) analysis of students' interest in STEM careers provide a new dimension in science curriculum research. The addition of predictive variables based on students' needs influence the model's consistency index and can contribute significantly to the impact of curriculum innovations for student commitment towards increasing STEM engagement.

\section{References}

Adegboyega, L. O. (2018). Influence of Achievement Motivation on Nigerian Undergraduates` Attitude towards Examination. International Journal of Instruction, 11(1), 77-88. https://doi.org/10.12973/iji.2018.1116a

Aytekin, I., Erdil, O., Erdoğmuş, N., \& Akgün, A. E. (2016). Academicians' career capital and career satisfaction: The mediation effect of research productivity. Educational Sciences: Theory $\mathcal{E}$ Practice, 16, 1921-1945. https://doi.org/10.12738/estp.2016.6.0412

Awang, Z. (2015). Structural Equation Modeling Using AMOS. MPWS Rich Publication.

Beerenwinkel, A., \& von Arx, M. (2016). Constructivism in Practice: an Exploratory Study of Teaching Patterns and Student Motivation in Physics Classrooms in Finland, Germany and Switzerland. Research in Science Education, 1-19. https://doi.org/10.1007/s11165-015-9497-3

Bergeron, L., \& Gordon, M. (2015). Establishing a STEM Pipeline: Trends in Male and Female Enrollment and Performance in Higher Level Secondary STEM Courses. International Journal of Science and Mathematics Education, 11(10), 44-57. http://doi.org/10.1007/s10763-015-9693-7

Creswell, J. W. (2014). Research Design Qualitative, Quantitative, and Mixed Methods Approaches. ( $4^{\text {th }}$ Edition). United States of America: SAGE Publications, Inc.

Deci, E. L., Olafsen, A. H., \& Ryan, R. M. (2017). Self-Determination Theory in Work Organizations : The State of a Science. Annual Review of Organizational Psychology and Organizational Behavior, 4, 19-43. https://doi.org/10.1146/annurev-orgpsych032516-113108

Duschl, R. A. (2019). Learning progressions: framing and designing coherent sequences for STEM education. Disciplinary and Interdisciplinary Science Education Research, 1, 4. https://doi.org/10.1186/s43031-019-0005-x

Fazilah, R., Umi, K. A. M, Othman, T., \& Siti A. H. (2020). Motivation to Learn Science as a Mediator between Attitude towards STEM and the Development of STEM Career Aspiration among Secondary School Students. Universal Journal of Educational Research, 8, 138-146. https://doi.org/10.13189/ujer.2020.081318

Gagné, M., \& Deci, E. L. (2005). Self-determination theory and work motivation. Journal of Organizational Behavior, 26(4), 331-362. https://doi.org/10.1002/job.322. 
Glynn, S. M., Brickman, P., Armstrong, N., \& Taasoobshirazi, G. (2011). Science motivation questionnaire II: Validation with science majors and nonscience majors. Journal of Research in Science Teaching, 48(10), 1159-1176. https:// doi.org/10.1002/tea.20442

Guan, M., Capezio, A., Restubog, S. L. D., Read, S., Lajom \& Li, M. (2016). The role of traditionality in the relationships among parental support, career decisionmaking self-efficacy and career adaptability. Journal of Vocational Behavior, 94(2), 114-123. http://doi.org/10.1016/j.jvb. 2016.02.018

Hair, J., Black, W. C., Babin, B. J., \& Anderson, R. E. (2010). Multivariate Data Analysis (7th ed.). Pearson Prentice Hall.

Hair, J., Gabriel, M., \& Patel, V. (2014). Amos Covariance-Based Structural Equation Modeling (CB-SEM): Guidelines on Its Application as a Marketing Research Tool. Brazilian Journal of Marketing, 13(2), 44-55. https://doi.org/10.5585/remark.v13i2.2718

Halim, L. (2018). STEM Education: Issues and Way Forward, STEM Education in Malaysia (pp. 37-58). Department of Higher Education, Ministry of Higher Education: Malaysia.

Hamjah, S. H., Ismail, Z., Rasit, R. M., \& Rozali, E. A. (2011). Methods of increasing learning motivation among students. Procedia - Social and Behavioral Sciences, 18, 138-147. https://doi.org/10.1016/j.sbspro.2011.05.021

Hooper, D., Coughlan, J., \& Mullen, M. R. (2008). Structural Equation Modelling: Guidelines for Determining Model Fit. The Electronic Journal of Business Research Methods, 6(1), 53-60. https:/ / doi.org/10.1108/978-1-78635-883-720161011

Hora, M. T., \& Oleson, A. K. (2017). Examining study habits in undergraduate STEM courses from a situative perspective. International Journal of STEM Education, 4(1), 1-19. https://doi.org/10.1186/s40594-017-0055-6

Hu, L., \& Bentler, P. M. (1998). Fit Indices in Covariance Structure Modeling : Sensitivity to Underparameterized Model Misspecification. Psychological Methods, 3(4), 424453. https:// doi.org/10.1037/1082-989x.3.4.424

Ibrahim, N. N., Ayub, A. F. M., Yunus, A. S. M., Mahmud, R., \& Bakar, K. A. (2019). Effects of higher-order thinking module approach on pupils performance at primary rural school. Malaysian Journal of Mathematical Sciences, 13(2), 211-229. https://doi.org/10.5901/mjss.2015.v6n2p494

Implementation Guide for Science, Technology, Engineering and Mathematics (STEM) in Teaching and Learning (2016). Curriculum Development Division Malaysia: Malaysia.

Khodabakhszadeh, H., Hosseinia, M., Abedi Moghadam, H., \& Ahmadi, F. (2018). EFL Teachers ' Creativity and Their Teaching`s Effectiveness : A Structural Equation Modelling Approach. International Journal of Instruction, 11(1), 227-238. https://doi.org/10.12973/iji.2018.11116a

Khong, H., Hassan, N. H., \& Ramli, N. (2017). Motivation and Gender Differences in Learning Spanish as a Foreign Language in a Malaysian Technical University. Malaysian Journal of Learning and Instruction, 14(2), 59-83. https:// doi.org/10.32890/mjli2017.14.2.3

Kline, R. B. (2011). Principles and practice of structural equation modelling (Vol. 156). New York: Guillford Press. http://doi.org/10.1038/156278a0

Lee, J. (2017). Influence of Career Motivation on Science Learning in Korean High-School Students. Journal of Mathematics Science and Technology Education, 8223(5), 15171538. http://doi.org/10.12973/ eurasia.2017.00683a

Leung, A. (2020). Boundary crossing pedagogy in STEM education. International Journal of STEM Education, 7, 15. https:/ / doi.org/10.1186/s40594-020-00212-9 
Li, Y., Wang, K., Xiao, Y., \& Froyd, J. E. (2020). Research and trends in STEM education: a systematic review of journal publications. International Journal of STEM Education, 7, 11. https://doi.org/10.1186/s40594-020-00207-6

McFadden, J., \& Roehrig, G. (2020). Missed expectations: teacher and coach tensions at the boundary of STEM integration in an elementary classroom. Disciplinary and Interdisciplinary Science Education Research, 2, 4. https://doi.org/10.1186/s43031020-00021-8

Nguyen, T. T., \& Deci, E. L. (2016). Can it be good to set the bar high? The role of motivational regulation in moderating the link from high standards to academic well-being. Learning and Individual Differences, 45, 245-251. https://doi.org/10.1016/j.lindif.2015.12.020

Nunnally, J. C. (1967). Psychometric theory. New York: McGraw-Hill Book Company. https://doi.org/10.1177/001316446802800128

Nunnally, J. C., \& Bernstein, I. R. (1994). Psychometric theory (3rd Edition). New York: McGraw-Hill Book Company. https://doi.org/10.1177/014662169501900308

Olafsen, A. H., Niemiec, C. P., Halvari, H., Deci, E. L., \& Williams, G. C. (2017). On the dark side of work: a longitudinal analysis using self-determination theory. European Journal of Work and Organizational Psychology, 26(2), 275-285. https://doi.org/10.1080/1359432x.2016.1257611

Dare, E. A., Ellis, J. A., \& Roehrig, G. H. (2018). Understanding science teachers' implementations of integrated STEM curricular units through a phenomenological multiple case study. International Journal of STEM Education, 5, 4. https:// doi.org/10.1186/s40594-018-0101-z

Ismail, R., Mahfodz, N. D., \& Sulaiman, N. (2016). Tahap dan penentu indeks modal sosial di Malaysia. Kajian Malaysia, 34(2), 101-121. http://dx.doi.org/10.21315/km2016.34.2.5

Reeve, E. M., Roehrig, G. H., \& Moore, T. J. (2014) The need for STEM teacher education development. In S. L. Green (Ed.) STEM education: how to train $21^{\text {st }}$ century teachers. New York: Science Publishers

Schreiber, J. B., Nora, A., Stage, F. K., Barlow, E. A., \& King, J. (2006). Modelling and Confirmatory Factor Analysis Results : A Review. The Journal of Education Research, 99(6), 323-338. https:// doi.org/10.3200/joer.99.6.323-338

Sekaran, U. (2013). Research Methods for Business A Skill Building Approach. (Third, Ed.) Research methods for business, 65(4). John Wiley \& Sons, Inc. http://doi.org/10.1017/CBO9781107415324.004

Sheldrake, R. (2016). Confidence as motivational expressions of interest, utility, and other influences: Exploring under-confidence and over-confidence in science students at secondary school. International Journal of Educational Research, 76, 50-65. https:// doi.org/10.1016/j.ijer.2015.12.001

Soni, A., \& Kumari, S. (2015). The Role of Parental Math Anxiety and Math Attitude in Their Children's Math Achievement. International Journal of Science and Mathematics Education, 9(19). https://doi.org/10.1007/s10763-015-9687-5

Zeynep, K. U., Dokme, I., \& Unlu, V. (2016). Adaptation of the Science, Technology, Engineering, and Mathematics Career Interest Survey (STEM-CIS) into Turkish. Eurasian Journal of Educational Research, 7(63), 21-38. https://doi.org/10.14689/ejer.2016.63.2 


\title{
Appendix 1
}

\section{Student Attitudes toward STEM Survey (S-STEM)}

\author{
Middle and High School
}

\begin{abstract}
Appropriate Use
The Middle/High School (6-12th) S-STEM Survey is intended to measure changes in students' confidence and efficacy in STEM subjects, 21st century learning skills, and interest in STEM careers. The survey is available to help program coordinators make decisions about possible improvements to their program.
\end{abstract}

The Friday Institute grants you permission to use these instruments for educational, non- commercial purposes only. You may use an instrument as is, or modify it to suit your needs, but in either case you must credit its original source. By using this instrument you agree to allow the Friday Institute to use the data collected for additional validity and reliability analysis. The Friday Institute will take appropriate measures to maintain the confidentiality of all data.

Recommended citation for this survey:

Friday Institute for Educational Innovation (2012). Middle and High School STEMStudent Survey. Raleigh, NC: Author.

The development of this survey was partially supported by the National Science Foundation under Grant No. 1038154 and by the Golden LEAF foundation.

The framework for part of this survey was developed from the following sources: Erkut, S., \& Marx, F. (2005). 4 schools for WIE (Evaluation Report). Wellesley, MA: Wellesley College, Center for Research on Women. Retrieved April 5, 2012 from http://www.coe.neu.edu/Groups/stemteams/evaluation.pdf

Bureau of Labor Statistics, U.S. Department of Labor, Occupational Outlook Handbook, 2010- 11 Edition. 


\section{DIRECTIONS}

There are lists of statements on the following pages. Please mark your answer sheets by marking how you feel about each statement. For example:

\begin{tabular}{|c|c|c|c|c|c|}
\hline Example 1: & $\begin{array}{c}\text { Strongly } \\
\text { Disagree }\end{array}$ & Disagree & $\begin{array}{c}\text { Neither } \\
\text { Agree nor } \\
\text { Disagree }\end{array}$ & Agree & $\begin{array}{c}\text { Strongly } \\
\text { Agree }\end{array}$ \\
\hline I like engineering. & $\bigcirc$ & $\bigcirc$ & $\bigcirc$ & $\bigcirc$ & $\bigcirc$ \\
\hline
\end{tabular}

As you read the sentence, you will know whether you agree or disagree. Fill in the circle that describes how much you agree or disagree.

Even though some statements are very similar, please answer each statement. This is not timed; work fast, but carefully.

There are no "right" or "wrong" answers! The only correct responses are those that are true for you. Whenever possible, let the things that have happened to you help you make a choice.

PLEASE FILL IN ONLY ONE ANSWER PER QUESTION 


\section{Your Future}

Here are descriptions of subject areas that involve math, science, engineering and/or technology, and lists of jobs connected to each subject area. As you read the list below, you will know how interested you are in the subject and the jobs. Fill in the circle that relates to how interested you are.

There are no "right" or "wrong" answers. The only correct responses are those that are true for you.

\begin{tabular}{|c|c|c|c|c|}
\hline & $\begin{array}{l}\text { Not at all } \\
\text { Interested }\end{array}$ & $\begin{array}{c}\text { Not So } \\
\text { Interested }\end{array}$ & Interested & $\begin{array}{c}\text { Very } \\
\text { Interested }\end{array}$ \\
\hline $\begin{array}{l}\text { 1. Physics: is the study of basic laws } \\
\text { governing the motion, energy, structure, } \\
\text { and interactions of matter. This can include } \\
\text { studying the nature of the universe. } \\
\text { (aviation engineer, alternative energy } \\
\text { technician, lab technician, physicist, } \\
\text { astronomer) }\end{array}$ & 0 & 0 & 0 & 0 \\
\hline $\begin{array}{l}\text { 2. Environmental Work: involves learning } \\
\text { about physical and biological processes } \\
\text { that govern nature and working to } \\
\text { improve the environment. This includes } \\
\text { finding and designing solutions to } \\
\text { problems like pollution, reusing waste and } \\
\text { recycling. (pollution control analyst, } \\
\text { environmental engineer or scientist, erosion } \\
\text { control specialist, energy systems engineer and } \\
\text { maintenance technician) }\end{array}$ & 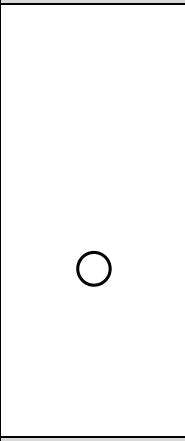 & 0 & 0 & 0 \\
\hline $\begin{array}{l}\text { 3. Biology and Zoology: involve the study } \\
\text { of living organisms (such as plants and } \\
\text { animals) and the processes of life. This } \\
\text { includes working with farm animals and } \\
\text { in areas like nutrition and breeding. } \\
\text { (biological technician, biological scientist, } \\
\text { plant breeder, crop lab technician, } \\
\text { animal scientist, geneticist, zoologist) }\end{array}$ & 0 & 0 & 0 & 0 \\
\hline $\begin{array}{l}\text { 4. Veterinary Work: involves the science of } \\
\text { preventing or treating disease in animals. } \\
\text { (veterinary assistant, veterinarian, livestock } \\
\text { producer, animal caretaker) }\end{array}$ & 0 & 0 & 0 & O \\
\hline $\begin{array}{l}\text { 5. Mathematics: is the science of numbers } \\
\text { and their operations. It involves } \\
\text { computation, algorithms and theory used } \\
\text { to solve problems and summarize data. } \\
\text { (accountant, applied mathematician, } \\
\text { economist, financial analyst, mathematician, } \\
\text { statistician, market researcher, stock market } \\
\text { analyst) }\end{array}$ & 0 & 0 & 0 & 0 \\
\hline
\end{tabular}




\begin{tabular}{|c|c|c|c|c|}
\hline $\begin{array}{l}\text { 6. Medicine: involves maintaining health } \\
\text { and preventing and treating disease. } \\
\text { (physician's assistant, nurse, doctor, } \\
\text { nutritionist, emergency medical technician, } \\
\text { physical therapist, dentist) }\end{array}$ & 0 & 0 & 0 & 0 \\
\hline $\begin{array}{l}\text { 7. Earth Science: is the study of earth, } \\
\text { including the air, land, and ocean. } \\
\text { (geologist, weather forecaster, archaeologist, } \\
\text { geoscientist) }\end{array}$ & 0 & 0 & 0 & 0 \\
\hline $\begin{array}{l}\text { 8. Computer Science: consists of the } \\
\text { development and testing of computer } \\
\text { systems, designing new programs and } \\
\text { helping others to use computers. (computer } \\
\text { support specialist, computer programmer, } \\
\text { computer and network technician, gaming } \\
\text { designer, computer software engineer, } \\
\text { information technology specialist) }\end{array}$ & 0 & $\bigcirc$ & 0 & 0 \\
\hline $\begin{array}{l}\text { 9. Medical Science: involves researching } \\
\text { human disease and working to find new } \\
\text { solutions to human health problems. } \\
\text { (clinical laboratory technologist, medical } \\
\text { scientist, biomedical engineer, epidemiologist, } \\
\text { pharmacologist) }\end{array}$ & 0 & 0 & 0 & 0 \\
\hline $\begin{array}{l}\text { 10. Chemistry: uses math and experiments } \\
\text { to search for new chemicals, and to study } \\
\text { the structure of matter and how it behaves. } \\
\text { (chemical technician, chemist, chemical } \\
\text { engineer) }\end{array}$ & 0 & 0 & 0 & 0 \\
\hline $\begin{array}{l}\text { 11. Energy: involves the study and } \\
\text { generation of power, such as heat or } \\
\text { electricity. (electrician, electrical engineer, } \\
\text { heating, ventilation, and air conditioning } \\
\text { (HVAC) technician, nuclear engineer, systems } \\
\text { engineer, alternative energy systems installer } \\
\text { or technician) }\end{array}$ & 0 & 0 & 0 & 0 \\
\hline $\begin{array}{l}\text { 12. Engineering: involves designing, } \\
\text { testing, and manufacturing new products } \\
\text { (like machines, bridges, buildings, and } \\
\text { electronics) through the use of math, } \\
\text { science, and computers. (civil, industrial, } \\
\text { agricultural, or mechanical engineers, welder, } \\
\text { auto-mechanic, engineering technician, } \\
\text { construction manager) }\end{array}$ & 0 & 0 & 0 & 0 \\
\hline
\end{tabular}




\section{Appendix 2}

\section{SCIENCE Motivation QUESTIONNAIRE II (SMQ-II)}

\section{(C) 2011 SHAWN M. GLYNN, UNIVERSITY OF GEORGIA, USA}

In order to better understand what you think and how you feel about your science courses, please respond to each of the following statements from the perspective of "When I am in a science course..."

\section{Statements}

Never 0 Rarely 1 Sometimes 2 Often 3 Always 4

01. The science I learn is relevant to my life.

02. I like to do better than other students on science tests.

03. Learning science is interesting.

04. Getting a good science grade is important to me.

05. I put enough effort into learning science.

06. I use strategies to learn science well.

07. Learning science will help me get a good job.

08. It is important that I get an "A" in science.

09. I am confident I will do well on science tests.

10. Knowing science will give me a career advantage.

11. I spend a lot of time learning science.

12. Learning science makes my life more meaningful.

13. Understanding science will benefit me in my career.

14. I am confident I will do well on science labs and projects.

15. I believe I can master science knowledge and skills.

16. I prepare well for science tests and labs.

17. I am curious about discoveries in science.

18. I believe I can earn a grade of " $A$ " in science.

19. I enjoy learning science.

20. I think about the grade I will get in science.

21. I am sure I can understand science.

22. I study hard to learn science. 
23. My career will involve science.

24. Scoring high on science tests and labs matters to me.

25. I will use science problem-solving skills in my career.

Note. The SMQ-II is copyrighted and registered. Go to http://www.coe.uga.edu/smq/ for permission and directions to use it and its discipline-specific versions such as the Biology Motivation Questionnaire II (BMQ- II), Chemistry Motivation Questionnaire II (CMQ-II), and Physics Motivation Questionnaire II (PMQ-II) in which the words biology, chemistry, and physics are respectively substituted for the word science. Versions in other languages are also available. 